\title{
Physicochemical and sensory analysis of salted cereals bars developed with
}

\section{vegetables rich in carotenoids ${ }^{1}$}

\author{
Avaliação físico-química e sensorial de barras de cereais salgadas elaboradas com vegetais ricos em \\ carotenoides
}

Evaluación físico-química y sensorial de barras de cereales salados elaboradas con vegetales ricos en carotenoides

Isabella Maciel Costa

ORCID: https://orcid.org/0000-0001-9648-9565 Universidade Federal de São João del-Rei, Brazil E-mail: bellamaciel@hotmail.com Sabrina Sandy Vasconcelos da Silva ORCID: https://orcid.org/0000-0003-0782-2069 Universidade Federal de São João del-Rei, Brazil

E-mail: sandyvasconcelos52@yahoo.com.br

Amanda Nayara Abreu Silva ORCID: https://orcid.org/0000-0002-9258-9179 Universidade Federal de São João del-Rei, Brazil E-mail: amandanayara71@gmail.com

Franciele Marques de Oliveira ORCID: https://orcid.org/0000-0001-7363-0984 Universidade Federal de São João del-Rei, Brazil

E-mail: francielemarques12@hotmail.com

Aline Cristina Arruda Gonçalves ORCID: https://orcid.org/0000-0003-1173-1346 Universidade Federal de São João del-Rei, Brazil E-mail: acarruda@ufsj.edu.br

Felipe Machado Trombete ORCID: https://orcid.org/0000-0002-8590-4142 Universidade Federal de São João del-Rei, Brazil E-mail: trombete@ufsj.edu.br Cíntia Nanci Kobori ORCID: https://orcid.org/0000-0002-6859-2730 Universidade Federal de São João del-Rei, Brazil E-mail: cintia@ufsj.edu.br

\begin{abstract}
Cereal bars are very appreciated by Brazilian consumers, especially because they are practical food with diverse flavors and compositions. They are easy to carry, do not need refrigeration, and can be a source of nutrients. However, salty cereal bars are not explored by food industries, and new formulations using healthier raw materials, such as rich in carotenoids vegetables, should be studied, especially concerning the acceptance of these new products by consumers. This study aimed to develop salted cereal bars with the addition of vegetables rich in carotenoids (dried tomato, dehydrated carrot and fresh kale). The physicochemical composition, texture analysis, and sensory acceptance were evaluated. Formulations with dried tomato and carrot were classified as a source of protein, while the cereal bars elaborated with kale can be classified as high protein content. The addition of cheese did not influence $(p>0.05)$ the hardness parameter in texture analysis. Samples added of dried tomato showed the highest concentrations of total carotenoids. In the sensory analysis, the addition of the cheese layer only increased the color acceptance for the kale cereals bar $(p<0.05)$. For the other sensory attributes, there was no significant difference $(p>0.05)$ between samples with or without cheese for the same flavor. The dried tomato and carrot cereal bars were the most accepted and did not differ statistically $(p>0.05)$ for all the attributes. Therefore, it was possible to develop salted cereal bars with the addition of vegetables rich in carotenoids and obtain good nutritional, physicochemical, and sensory characteristics.

Keywords: Snacks; Cereal products; Dried tomato; Carrot; Kale; Vegetable protein.
\end{abstract}

\footnotetext{
${ }^{1}$ Trabalho apresentado no CBCP 2020 - Congresso on-line Brasileiro de Tecnologia de Cereais e Panificação, selecionado para publicação na forma de artigo completo.
} 


\begin{abstract}
Resumo
As barras de cereais são muito apreciadas pelos consumidores brasileiros, especialmente por serem alimentos práticos, com diversos sabores e composições. Elas são fáceis de transportar, não precisam de refrigeração e podem ser uma boa fonte de nutrientes. Entretanto, as barras de cereais salgadas não são exploradas pelas indústrias de alimentos e novas formulações utilizando matérias-primas mais saudáveis, como os vegetais ricos em carotenoides, devem ser estudadas, principalmente com relação à aceitação desses novos produtos pelos consumidores. O objetivo do trabalho foi desenvolver formulações de barras de cereais salgadas com adição de vegetais ricos em carotenoides (tomate seco, cenoura desidratada e couve in natura). Foram avaliadas a composição físico-química, a análise de textura e a aceitação sensorial. As formulações de tomate seco e cenoura foram classificadas como fonte de proteínas, enquanto as de couve foram caracterizadas como alimentos com alto conteúdo de proteínas. $\mathrm{O}$ queijo não interferiu significativamente na textura $(\mathrm{p}>0,05)$. As amostras de tomate seco apresentaram as maiores concentrações de carotenoides totais enquanto as de couve exibiram as menores. $\mathrm{Na}$ análise sensorial, a adição da camada de queijo apenas aumentou a aceitação da cor para a barra de cereais de couve ( $\mathrm{p}<0,05)$. Para os demais atributos sensoriais, não houve diferença significativa $(p>0,05)$ entre as amostras com ou sem queijo para o mesmo sabor. As barras de cereais de sabor tomate seco e cenoura foram as mais aceitas, não diferindo estatisticamente entre si $(\mathrm{p}>0,05)$ para todos os atributos. Portanto, foi possível desenvolver barras de cereais salgadas com adição de vegetais ricos em carotenoides e obter boas características nutricionais, físico-químicas e sensoriais.
\end{abstract}

Palavras-chave: Petisco; Produtos derivados de cereais; Tomate seco; Cenoura; Couve; Proteína vegetal.

\title{
Resumen
}

Las barritas de cereales son muy apreciadas por los consumidores brasileños, sobre todo porque son alimentos prácticos con diversos sabores y composiciones. Son fáciles de llevar, no necesitan refrigeración y pueden ser una fuente de nutrientes. Sin embargo, las barritas de cereales saladas no son exploradas por las industrias alimentarias, y deberían estudiarse nuevas formulaciones que utilicen materias primas más saludables, como las verduras ricas en carotenoides, especialmente en lo que respecta a la aceptación de estos nuevos productos por parte de los consumidores. El objetivo del trabajo fue desarrollar formulaciones de barras de cereales saladas con la adición de vegetales ricos en carotenoides (tomate seco, zanahoria deshidratada y col). Se evaluó la composición centesimal, las características fisicoquímicas y los aspectos sensoriales. Las formulaciones de tomates y zanahorias secas se clasificaron como fuente de proteínas, mientras que las de col rizada se caracterizaron como alimentos con un alto contenido de proteínas. El queso no interfirió significativamente en la textura ( $>$ > 0.05). Las muestras de tomate seco mostraron las concentraciones más altas de carotenoides totales, mientras que las muestras de col rizada mostraron las más bajas. En el análisis sensorial, la adición de la capa de queso solo incrementó la aceptación del color para la barra de cereal de col $(\mathrm{p}<0.05)$. Para los otros atributos sensoriales, no hubo diferencia significativa $(\mathrm{p}>0.05)$ entre muestras con o sin queso para el mismo sabor. Las barras de cereal con sabor tomate seco y zanahoria fueron las más aceptadas y no difirieron estadísticamente entre sí ( $\mathrm{p}>0.05)$ para todos los atributos. Por tanto, fue posible desarrollar barritas de cereales saladas con la adición de vegetales ricos en carotenoides y obtener buenas características nutricionales, físico-químicas y sensoriales.

Palabras clave: Bocadillo; Productos de cereales; Tomate seco; Zanahoria; Col rizada; Proteína vegetal.

\section{Introduction}

The consumption of quick snacks has become a tendency in the market, but at the same time, the health concern is higher, making consumers look for healthier food which brings more benefits, such as reducing the risk of diseases (Sampaio et al., 2009; Farinazzi-Machado et al., 2012). Thus, recently, there is a considerable search for industrialized products that are practical and meet the needs of healthiness.

Diets rich in vegetables can reduce the risk of non-communicable diseases. Vegetables are the main source of vitamin C, fibers, and bioactive compounds, being a great source of energy, protein, minerals, and vitamins. The bioactive compounds function in many different ways related to the method of action, as well as physiological targets, with antioxidant action being the most common function (Bastos et al., 2009). In vegetables, carotenoids can be a source of vitamin A, which is important for vision and with high antioxidant activity. Carotenoids are also responsible for the orange, yellow and red colors, although their coloring is often hidden by the green color due to the presence of chlorophyll (Schiozer \& Barata, 2007).

Carotenoids have a fundamental use in the food industry as a natural dye, granting color to colorless food, establishing the color lost in steps of processing and storing or standardizing coloring of certain products. However, due to the current tendency of health and wellbeing concerns, these dyes have been applied to products to enrich and bring benefits to health 
(Valduga et al., 2009).

Cereal bars hit the market in the early 90s and are a practical and quick option for daily life. They offer good supplementation of calories and nutritious sources, such as lipids, proteins, fibers, vitamins, and minerals (Freitas \& Moretti, 2006a; Farinazzi-Machado et al., 2012; Melo et al., 2020).

The cereal bars market grows around $20 \%$ per year, and the increasing consumption is due to convenience and practicality, easy to carry, do not need refrigeration, and can be a source of fibers with low content of fat (Freitas \& Moretti, 2006b; Bampi et al., 2016; Marchese \& Novello, 2017; Melo et al., 2020). Therefore, in order to meet the increase in consumer demand, industries need to search for new formulations, diversifying flavors and attributes. Fortification with vitamins, minerals, proteins, and the increasing of fiber content of cereal bars have been studied recently (Sampaio et al., 2009; Bampi et al., 2016; Silva et al., 2019). Salty cereal bars also have been developed with the addition of sesame, oregano, dehydrated onion, garlic and flavoring (Bampi et al., 2016; Marchese \& Novello, 2017). Despite this, savory flavors are still scarce in Brazilian supermarkets and it is difficult to find these products.

Dehydrated vegetables have been used in the food industry as seasonings - parsley, garlic, or as dyes - carrots, beets (Costa \& Rosa, 2010; Marchese \& Novello, 2017; Mesquita et al., 2017; Silva et al., 2019). The development of salted cereal bars with added foods that may have functional potential, such as sesame, oats, peanuts, flaxseed, textured soy protein, is an innovative idea to gain market share (Marchese \& Novello, 2017). In addition to offering more alternatives of savory flavors to customers, adding vegetable sources of carotenoids in their formulation would also improve the nutritional value and functional appeal of cereal bars.

Thus, this study aimed to develop formulations of salted cereal bars with the addition of vegetables rich in carotenoids (tomato, carrot, and kale), and characterize them through physicochemical analyses and, also, to evaluate the sensory acceptance and purchase intention of these new products by consumers.

\section{Methodology}

\subsection{Material}

The selected design was a study of a quantitative nature (Pereira et al., 2018). The ingredients (flaked cereals, provolone cheese, spices, dried tomato, carrot and kale) were purchased in commercial establishments in Sete Lagoas - MG, all of them were suitable for use in food products and within the shelf life declared.

\subsection{Formulation of the salted cereal bars}

The salt cereal bars were prepared following the methodologies presented by Rodrigues Júnior et al. (2011) and Marchese \& Novello (2017), with adaptations. After defining a control-based formulation, without adding vegetables, elaborated only with oat flakes, peanuts, flaxseed, sesame, rice flakes, garlic powder, dehydrated onion, oregano, smoke powder, salt, provolone cheese, Brazilian cream cheese, and water, six new formulations were developed with the addition of vegetables rich in carotenoids (dried tomato, carrot or kale), with or without a layer of provolone cheese on the surface of the bars, are presented in Table 1. 
Table 1: Formulations for the preparation of salted cereal bars with the addition of vegetables (T, C, and K) and with a layer of provolone cheese (TC, CC, and $\mathrm{KC}$ ).

\begin{tabular}{|c|c|c|c|c|c|c|}
\hline \multirow{2}{*}{ Ingredients (\%) } & \multicolumn{6}{|c|}{ Formulations of salted cereal bars } \\
\hline & $\mathbf{T}$ & TC & $\mathbf{C}$ & $\mathbf{C C}$ & $\mathbf{K}$ & $\overline{\mathrm{KC}}$ \\
\hline Dried tomato & 33 & 29.1 & - & - & - & - \\
\hline Dehydrated carrot & - & - & 20 & 17.6 & - & - \\
\hline Fresh kale & - & - & - & - & 12 & 10.6 \\
\hline Oat flakes & 9 & 7.9 & 9.5 & 8.4 & 12 & 10.6 \\
\hline Peanuts & 9 & 7.9 & 9.5 & 8.4 & 12 & 10.6 \\
\hline Flaxseed & 3 & 2.6 & 3.4 & 3 & 4.9 & 4.3 \\
\hline Sesame & 3 & 2.6 & 3.4 & 3 & 4.9 & 4.3 \\
\hline Rice flakes & 11 & 9.7 & 11 & 9.7 & 13 & 11.4 \\
\hline Garlic powder & 0.4 & 0.4 & 0.4 & 0.4 & 0.4 & 0.4 \\
\hline Dehydrated onion & 0.3 & 0.3 & 0.3 & 0.3 & 0.3 & 0.3 \\
\hline Dehydrated oregano & 0.2 & 0.2 & 0.2 & 0.2 & 0.2 & 0.2 \\
\hline Smoke powder & 0.5 & 0.5 & 0.5 & 0.5 & 0.5 & 0.5 \\
\hline Salt & 0.8 & 0.7 & 0.8 & 0.7 & 0.8 & 0.7 \\
\hline Provolone cheese & 6 & 5.3 & 6 & 5.3 & 6 & 5.3 \\
\hline $\begin{array}{l}\text { Brazilian cream } \\
\text { cheese }\end{array}$ & 15 & 13.2 & 20 & 17.6 & 18 & 15.9 \\
\hline Water & 8.8 & 7.8 & 15 & 13.2 & 15 & 13.2 \\
\hline $\begin{array}{l}\text { Layer of provolone } \\
\text { cheese }\end{array}$ & - & 11.7 & - & 11.7 & - & 11.7 \\
\hline
\end{tabular}

$\mathrm{T}$ - salted cereal bar of dried tomato; TC - salted cereal bar of dried tomato with a layer of cheese; C - salted cereal bar of dehydrated carrot; $\mathrm{CC}$ - salted cereal bar of dehydrated carrot with a layer of cheese; $\mathrm{K}$ - salted cereal bar of fresh kale and KC salted cereal bar of fresh kale with a layer of cheese. Source: Authors (2020).

Carrot was grated and previously oven dried at $160{ }^{\circ} \mathrm{C}$ (Lucadema model LUCA-80/150) to be added to the control formulation. The commercial dried tomato was manually cut into small squares $(1.0 \mathrm{~cm}$ x $1.0 \mathrm{~cm})$ and the fresh kale in thin strips $(1.0 \mathrm{~cm} \times 1.5 \mathrm{~cm})$.

Samples without the layer of cheese were named $\mathrm{T}$ for the dried tomato, $\mathrm{C}$ for the dehydrated carrot, and $\mathrm{K}$ for the fresh kale. Those with the layer of cheese were named TC for the dried tomato with cheese, $\mathrm{CC}$ for the dehydrated carrot with cheese and $\mathrm{KC}$ for fresh kale with cheese.

\subsection{Preparation of salted cereal bars}

Dry ingredients (oat flakes, peanuts, flaxseed, sesame, rice flakes, garlic powder, dehydrated onion, oregano, smoke powder, and salt) were weighed and manually mixed until homogeneous distribution. Subsequently, binders or wet ingredients (provolone cheese, Brazilian cream cheese, and water) were heated under stirring until obtaining a homogeneous liquid. The two fractions (dry and binders) were mixed until a dough was obtained, which was placed on a stainless-steel surface and baked in a conventional oven at $180{ }^{\circ} \mathrm{C}$ for $20 \mathrm{~min}$. The dough was cooled for $20 \mathrm{~min}$ at room temperature and was cut to standard dimensions. In formulations with a provolone cheese layer, the layer was added to the surface of the dough before 
baking.

\subsection{Physicochemical analysis}

\subsubsection{Centesimal composition}

Ash content, moisture, and protein were determined according to the Instituto Adolfo Lutz (2008), methods 018/IV, 012/IV and 036/IV, respectively. For protein content, a value of 6.25 was used as a conversion factor of nitrogen into protein. Lipid content was determined according to the Soxhlet method described by the American Oil Chemists' Society - AOCS Bc 3-49 (1993). Carbohydrates were determined by difference.

\subsubsection{Objective color and total carotenoids analysis}

Color measurements were done in nine repetitions using a calibrated portable colorimeter (Minolta Chroma meter CR210) and the results were expressed in CIELAB system of color, which $L^{*}$ represents the brightness, $a^{*}$ the red-green axis, and b* the yellow-blue axis.

Total carotenoids content was quantified by a spectrophotometric method (Rodriguez-Amaya, 1999) in three repetitions, using absorbance at $450 \mathrm{~nm}$ on a UV/VIS Femto spectrophotometer (model 700S). The results were expressed in $\mu \mathrm{g} / \mathrm{g}$ of the sample analyzed.

\subsubsection{Instrumental firmness analysis}

The firmness of each cereal bar was evaluated in triplicate at room temperature in a texturometer TA XT P/US (Stable Micro Systems) equipped with a Warner Bratzler V Slot Blade - HDP/WBV probe. The test was done using the parameters of compression strength measurement, pre-test speed $(1.5 \mathrm{~mm} / \mathrm{s})$, test speed $(2.0 \mathrm{~mm} / \mathrm{s})$, post-test speed $(10 \mathrm{~mm} / \mathrm{s})$ and distance (17 mm) (Silva et al., 2009).

\subsection{Sensory analysis}

The sensory evaluation was conducted in individual cabins using white light with a sensory panel composed by 100 consumers aged above 18 yr and recruited at Federal University of São João del Rei, Sete Lagoas Campus.

Samples were presented in monadic form and coded with three random numbers. Samples had approximately $3.0 \mathrm{~cm}$ x $2.0 \mathrm{~cm} \times 1.5 \mathrm{~cm}$ and were served in plastic dishes with a plastic cup containing water. For the acceptance test, each assessor received a form in which they evaluated the attributes of color, aroma, flavor, texture and overall appearance. A 9-point structured hedonic scale containing extremes that indicated "disliked extremely" (1) to "liked extremely" (9) was used. For the purchase intent test, the hedonic scale contained a 5-point scale which extremes indicated "I definitely would not buy" (1) to "I would definitely buy" (5).

Consumers also answered a questionary about the frequency of consumption of cereal bars, the reasons for this, and the frequency of physical activities. In addition, a list of adjectives was presented for consumers to mark those that best described the tasted products.

The acceptability of the products for the overall appearance was calculated (Equation 1) by the acceptability index (AI), according to Dutcosky (2011).

$$
\mathrm{AI}(\%)=(\mathrm{A} / \mathrm{B}) \times 100 \quad(\text { Equation } 1)
$$

Where, "A" is the average of the acceptance test results for each product and "B" is the highest score obtained in the 
acceptance test for each product.

\subsection{Statistical analysis}

Data obtained was analyzed statistically by ANOVA and Tukey test with $5 \%$ of significance $(p \leq 0,05)$ using the software Statistica version 13.3 (Tibco Software Inc, 2017).

\section{Results and Discussion}

\subsection{Physicochemical analysis}

\subsubsection{Centesimal Composition}

The results of the centesimal composition of the salted cereal bars developed are shown in Table 2.

Table 2: Centesimal composition of salted cereal bars.

\begin{tabular}{lccccc}
\hline \multirow{2}{*}{ Formulation } & \multicolumn{5}{c}{ Parameters (\%) } \\
\cline { 2 - 6 } & Moisture & Protein & Lipid & Ash & Carbohydrate* $^{\text {* }}$ \\
\hline T & $16.48 \pm 0.15^{\mathrm{e}}$ & $10.74 \pm 0.37^{\mathrm{b}}$ & $24.68 \pm 0.71^{\mathrm{a}}$ & $5.78 \pm 0.10^{\mathrm{a}}$ & 42.33 \\
TC & $28.52 \pm 0.72^{\mathrm{b}}$ & $10.69 \pm 0.14^{\mathrm{b}}$ & $21.44 \pm 0.16^{\mathrm{b}}$ & $5.42 \pm 0.28^{\mathrm{b}}$ & 33.93 \\
$\mathbf{C}$ & $24.43 \pm 0.20^{\mathrm{c}}$ & $10.38 \pm 0.48^{\mathrm{b}}$ & $14.37 \pm 0.57^{\mathrm{d}}$ & $3.80 \pm 0.15^{\mathrm{c}}$ & 47.03 \\
$\mathbf{C C}$ & $32.62 \pm 0.46^{\mathrm{a}}$ & $10.15 \pm 0.48^{\mathrm{b}}$ & $10.78 \pm 0.52^{\mathrm{e}}$ & $3.98 \pm 0.04^{\mathrm{c}}$ & 42.47 \\
$\mathbf{K}$ & $21.72 \pm 0.14^{\mathrm{d}}$ & $12.64 \pm 0.59^{\mathrm{a}}$ & $17.37 \pm 0.82^{\mathrm{c}}$ & $4.14 \pm 0.09^{\mathrm{c}}$ & 44.13 \\
KC & $25.62 \pm 0.74^{\mathrm{c}}$ & $12.66 \pm 0.36^{\mathrm{a}}$ & $15.85 \pm 0.54^{\mathrm{cd}}$ & $3.72 \pm 0.10^{\mathrm{c}}$ & 42.16 \\
\hline
\end{tabular}

Means \pm standard deviation with the same letters in the same column do not differ statistically ( $\mathrm{p} \leq 0.05)$ by the Tukey test. Results expressed on moist basis. T - salted cereal bar of dried tomato; TC - salted cereal bar of dried tomato with a layer of cheese; $\mathrm{C}$ - salted cereal bar of dehydrated carrot; CC - salted cereal bar of dehydrated carrot with a layer of cheese; $\mathrm{K}$ - salted cereal bar of fresh kale and KC salted cereal bar of fresh kale with a layer of cheese. * No represent mean values (obtained by calculation). Source: Authors (2020).

The samples with a superficial layer of provolone cheese (TC, CC, and KC) had higher moisture content $(\mathrm{p} \leq 0.05)$ than those without it (T, C, and $\mathrm{K}$ ). Therefore, the increase in the amount of cheese in formulation contributed to the elevation in salted cereal bars moisture content. The sample T had presented the lowest moisture content while sample CC showed the highest.

It was observed that all formulations had high moisture content, varying from $16.48 \%$ to $32.62 \%$. There is no specific legislation for cereal bar in Brazil, however, CNNPA (National Commission of Norms and Standards for Food) Resolution No.12 of 1978 (Brasil, 1978) establishes a maximum moisture content of 15\% for products derivative from cereals; therefore, the results found by this work were superior to those recommended by such legislation, despite not representing a problem in product quality.

A similar result was also obtained by Marchese and Novello (2017), who found $18.97 \%$ for a salty cereal bar flavored with garlic and oregano. However, Tramujas et al. (2017) when developing salted cereal bars with chia formulated with different binding agents (collagen, guar gum, xanthan gum e psyllium) found moisture values varying from 5.80 to $9.69 \%$ and Haddad et al. (2020) reported 2.45 to $3.12 \%$ for salted food bars elaborated with different concentrations of binding agents (modified starch, hydrolyzed collagen, and acacia gum) with low caloric value.

Moisture is one of the main product conservation indicators and the higher the moisture content the more susceptible to deterioration (Gava et al., 2009). In this way, it is interesting to evaluate the stability of the developed products during storage. Also, the possibility of reducing the fraction of binding agents (wet) or increasing the temperature and/or the time of 
baking should be considered in future studies.

Haddad et al. (2020) baked the bars in a forced ventilation oven for drying at $65{ }^{\circ} \mathrm{C}$ for 20 hours. Silva et al. (2019) elaborated sweet cereal bars with carrots or beets and concluded that the addition favored the bars appearance by the color of these vegetables, however, the high humidity also impaired their texture and crispness.

There was no significant difference $(\mathrm{p}>0.05)$ in protein concentration when the cheese layer was added for the same flavor. The samples containing kale showed a higher amount of protein than samples containing carrot and dried tomato. The kale formulations had a lower proportion of vegetables and, consequently, higher concentrations of oat, peanut, flaxseed, and sesame that have, respectively, $13.9 \%, 27.2 \%, 14.1 \%$ e $21.2 \%$ of proteins (Nepa/Unicamp, 2011), contributing to increasing this parameter in this sample.

The protein content ranged from 10.15 to $12.66 \%$ among the formulations. In a study conducted by Freitas \& Moretti (2016b), a cereal bar was developed based on wheat germ, oat, and textured soy protein, enriched with ascorbic acid and $\alpha$ tocopherol acetate, and average protein content of $15.31 \%$ was found, which is higher than commercial cereal bars that have about $4.4 \%$ of protein.

According to Resolution of the Collegiate Board of Directors (RDC) No. 54, of November 12, 2012 (Brasil, 2012), a food can be considered "source of protein" or with "high protein content" when it has at least $6 \mathrm{~g}$ of protein/100 $\mathrm{g}$ of the product and $12 \mathrm{~g}$ of protein/100 $\mathrm{g}$ of product, respectively. Therefore, the samples T, TC, C e CC can be considered as a source of protein, while the samples $\mathrm{K} \mathrm{e} \mathrm{KC}$ can be classified as high protein content. This result is in line with the consumers' demands, who nowadays are interested in a healthy diet, rich in proteins, especially those who practice physical activity and have greater protein-energy needs (Bezerra \& Macedo, 2013).

The samples that had the layer of cheese (TC, CC and KC) had lower lipid content than those that did not contain for the same flavor (T, C and $\mathrm{K}$ ). This is probably because by adding the cheese layer, proportionally, the other ingredients of the formulations were reduced and, among them, those that most collaborate for the lipid content (oilseeds). According to the Brazilian Food Composition Table (Unicamp, 2011), peanut seeds contain about 43.9\% oil, sesame seeds have 50.4\% and flaxseed contain $32.3 \%$. These seeds have in their composition a greater amount of unsaturated fatty acids than saturated, which are mainly oleic acid $(\omega 9)$, linoleic $(\omega 6)$, and linolenic $(\omega 3)$. However, the difference was not significant $(\mathrm{p}>0.05)$ for kale flavor samples (K e KC).

Tramujas (2017) found lipid levels higher than those obtained in this work, varying from 29.10 to $32.47 \%$, also using oilseeds in their formulations, like peanut, sesame, flaxseed, Brazilian nut, and chia seed. The dried tomatoes bars (T and TC) showed the highest percentages of lipids because industrial dried tomatoes containing soybean oil were used, which may have contributed to an increase in this content.

Referring to the ash values, only the $\mathrm{T}$ and $\mathrm{TC}$ samples differed from each other and also from the other samples ( $\mathrm{p} \leq$ 0.05). The observed values were close to those obtained in the study of Marchese and Novello (2017) that obtained ash content of 5.09\% for the developed formulation and by Haddad et al. (2020) which found levels between 4.22 and 5.02\% for salty bars added with different binding agents.

For carbohydrates, the values obtained were between 33.93 and $47.03 \%$, a range that is similar to those reported in the literature for salted cereal bars (Marchese \& Novello, 2017, Haddad et al., 2020).

\subsubsection{Objective color and total carotenoids analysis}

The parameters of the color analysis and the total carotenoids content of the cereal bars are presented in Table 3 . 
Table 3: Parameters of the color analysis and total carotenoids content of the salted cereal bars.

\begin{tabular}{lccccc}
\hline \multirow{2}{*}{ Formulation } & \multicolumn{5}{c}{ Parameters (\%) } \\
\cline { 2 - 6 } & Moisture & Protein & Lipid & Ash & Carbohydrate* \\
\hline T & $16.48 \pm 0.15^{\mathrm{e}}$ & $10.74 \pm 0.37^{\mathrm{b}}$ & $24.68 \pm 0.71^{\mathrm{a}}$ & $5.78 \pm 0.10^{\mathrm{a}}$ & 42.33 \\
TC & $28.52 \pm 0.72^{\mathrm{b}}$ & $10.69 \pm 0.14^{\mathrm{b}}$ & $21.44 \pm 0.16^{\mathrm{b}}$ & $5.42 \pm 0.28^{\mathrm{b}}$ & 33.93 \\
$\mathbf{C}$ & $24.43 \pm 0.20^{\mathrm{c}}$ & $10.38 \pm 0.48^{\mathrm{b}}$ & $14.37 \pm 0.57^{\mathrm{d}}$ & $3.80 \pm 0.15^{\mathrm{c}}$ & 47.03 \\
$\mathbf{C C}$ & $32.62 \pm 0.46^{\mathrm{a}}$ & $10.15 \pm 0.48^{\mathrm{b}}$ & $10.78 \pm 0.52^{\mathrm{e}}$ & $3.98 \pm 0.04^{\mathrm{c}}$ & 42.47 \\
$\mathbf{K}$ & $21.72 \pm 0.14^{\mathrm{d}}$ & $12.64 \pm 0.59^{\mathrm{a}}$ & $17.37 \pm 0.82^{\mathrm{c}}$ & $4.14 \pm 0.09^{\mathrm{c}}$ & 44.13 \\
KC & $25.62 \pm 0.74^{\mathrm{c}}$ & $12.66 \pm 0.36^{\mathrm{a}}$ & $15.85 \pm 0.54^{\mathrm{cd}}$ & $3.72 \pm 0.10^{\mathrm{c}}$ & 42.16 \\
\hline
\end{tabular}

Means \pm standard deviation with the same letters in the same column do not differ statistically $(\mathrm{p} \leq 0.05)$ by the Tukey test. Results expressed on moist basis. T - salted cereal bar of dried tomato; TC - salted cereal bar of dried tomato with a layer of cheese; $\mathrm{C}$ - salted cereal bar of dehydrated carrot; CC - salted cereal bar of dehydrated carrot with a layer of cheese; K - salted cereal bar of fresh kale and KC salted cereal bar of fresh kale with a layer of cheese. * No represent mean values (obtained by calculation). Source: Authors (2020).

The color analysis showed a greater variation among the parameters evaluated (high standard deviation), which was already expected due to the heterogeneity of the cereal bars. Different ingredients were used in their formulations that were not evenly distributed, there may be a greater or lesser amount of a certain component at a specific point in the reading analysis.

The values of brightness $\left(\mathrm{L}^{*}\right)$ increased significantly $(\mathrm{p} \leq 0.05)$ when adding the cheese layer to the dried tomato samples, indicating that the dairy derivative contributed to their clarity. The $\mathrm{T}$ sample was the darkest one since it had the lowest value of $\mathrm{L}^{*}$.

For the redness-greenness coordinates $\left(\mathrm{a}^{*}\right)$, there was no significant difference $(\mathrm{p}>0.05)$ between samples with and without the cheese layer for the same flavor. The T, TC, C, and CC samples showed no significant difference between each other ( $\mathrm{p}>0.05)$ and exhibited positive and higher values than the kale samples ( $\mathrm{K}$ and $\mathrm{KC})$, indicating that they have a greater tendency to red color.

For coordinate $\left(b^{*}\right)$, there was a significant difference $(\mathrm{p} \leq 0.05)$ between $\mathrm{T}$ and $\mathrm{TC}$, whereas, for the other flavors, there was no difference when the layer of cheese was added ( $p>0.05)$. All samples showed a positive value, which indicates a higher tendency to yellow color. However, the $\mathrm{C}$ and $\mathrm{CC}$ formulations showed higher values $(\mathrm{p} \leq 0.05)$ than the other samples, thus exposing a greater propensity to yellow, which is due to the presence of $\beta$-carotene in carrots (Mesquita et al., 2017).

For the total carotenoids content, there was no significant difference $(p>0.05)$ between formulations with or without cheese for the same flavor. The dried tomato samples showed the highest concentrations of total carotenoids, the carrot samples were intermediate and the kale samples showed the lowest concentrations.

Dried tomatoes have about $529 \mu \mathrm{g} / \mathrm{g}$ of total carotenoids, with lycopene being the predominant carotenoid in the vegetable (491 $\mu \mathrm{g} / \mathrm{g}$ ) (Rodriguez-Amaya, 2008). Lycopene is the carotenoid that has the highest antioxidant action (greater ability to sequester singlet oxygen), besides reducing the risk of diseases such as cervical, prostate, lung, and esophageal cancer, cardiovascular disease, and high blood pressure (Rodriguez-Amaya, 2008; Costa \& Rosa, 2010).

Medeiros et al. (2011) found $469.63 \mu \mathrm{g} / \mathrm{g}$ of total carotenoids in dehydrated carrots. The carrot has as the majority carotenoid the $\beta$-carotene which has the highest activity of provitamin A which helps in reproduction, growth, and vision and participates in protein synthesis and cell differentiation (Rodriguez-Amaya, 2008; Whitney \& Rolfes, 2013).

Nachtigall et al. (2007) determined the total carotenoid content in kale and found $79.90 \mu \mathrm{g} / \mathrm{g}$. According to RodriguezAmaya (2008), the amount of lutein found in kale for ripe leaves is $50 \mu \mathrm{g} / \mathrm{g}$. Lutein is one of the constituents of the pigmentation of the macula of the human retina and is related to the protection of diseases, such as macular degeneration and cataracts since it plays an antioxidant and filtering role for blue light (Rodriguez-Amaya, 2008; Costa \& Rosa, 2010). 
Thus, each cereal bar can be associated with different health benefits. The concentration of total carotenoids in dried tomatoes is higher than that of carrots, which is higher than that of kale, confirming the results found in cereal bars.

\subsubsection{Instrumental firmness analysis}

Table 4 describes the results obtained in the instrumental firmness analysis.

Table 4: Compression strength obtained in the instrumental firmness analysis for salted cereal bars.

\begin{tabular}{cc}
\hline Formulation & Compression strength $(\mathbf{g F})$ \\
\hline T & $7203.63 \pm 0.47^{\mathrm{a}}$ \\
TC & $6507.99 \pm 2.97^{\mathrm{ab}}$ \\
$\mathbf{C}$ & $3325.64 \pm 1.94^{\mathrm{abc}}$ \\
$\mathbf{C C}$ & $5829.53 \pm 1.58^{\mathrm{abc}}$ \\
$\mathbf{K}$ & $2281.27 \pm 0.50^{\mathrm{bc}}$ \\
KC & $1649.89 \pm 0.75^{\mathrm{c}}$ \\
\hline
\end{tabular}

Means \pm standard deviation with the same letters in the same column do not differ statistically $(\mathrm{p} \leq 0.05)$ by the Tukey test. T - salted cereal bar of dried tomato; TC - salted cereal bar of dried tomato with a layer of cheese; C - salted cereal bar of dehydrated carrot; CC - salted cereal bar of dehydrated carrot with a layer of cheese; K - salted cereal bar of fresh kale and KC salted cereal bar of fresh kale with a layer of cheese. Source: Authors (2020).

There was great variation among the averages obtained for the compression force, which was already expected due to the diversity of structures present in cereals bars base formulation (oat flakes, peanuts, flaxseed, sesame, rice flakes, and condiments) and the different vegetables added. However, no significant difference ( $\mathrm{p}>0.05)$ between the samples with and without cheese layers for the same vegetable was observed which shows that the layer did not interfere in texture. The formulation $\mathrm{T}$ presented the highest cutting force and, therefore, the hardest and $\mathrm{KC}$ was the softest (lowest strength). Dried tomato composition may have contributed to the binding action between the dry ingredients in this formulation, increasing the firmness of the cereal bar.

Silva et al. (2009) developed cereal bars added from 10 to $40 \%$ of the industrial waste of passion fruit to replace oat flakes and reported values of force 1 (cut) similar to those of this work (2700,3 to $5423,7 \mathrm{gF})$ using the same parameters in instrumental texture analysis.

\subsection{Sensory analysis}

The averages of the scores obtained for each attribute in the sensory analysis (scale from 1 to 9 ) and purchase intent (scale 1 to 5 ) are described in Table 5. 
Table 3: Scores obtained in the sensory analysis for the parameters of color, aroma, flavor, texture, overall appearance, and purchase intent.

\begin{tabular}{lcccccc}
\hline Formulation & Color & Aroma & Flavor & Texture & $\begin{array}{c}\text { Overall } \\
\text { appearance }\end{array}$ & $\begin{array}{c}\text { Purchase } \\
\text { intent }\end{array}$ \\
\hline T & $7.02^{\mathrm{ab}}$ & $6.90^{\mathrm{abc}}$ & $6.46^{\mathrm{a}}$ & $6.68^{\mathrm{abc}}$ & $6.60^{\mathrm{ab}}$ & $3.37^{\mathrm{a}}$ \\
$\mathbf{T C}$ & $7.21^{\mathrm{a}}$ & $7.17^{\mathrm{a}}$ & $6.91^{\mathrm{a}}$ & $6.82^{\mathrm{a}}$ & $6.91^{\mathrm{a}}$ & $3.63^{\mathrm{a}}$ \\
$\mathbf{C}$ & $7.00^{\mathrm{ab}}$ & $6.95^{\mathrm{ab}}$ & $6.61^{\mathrm{a}}$ & $6.78^{\mathrm{ab}}$ & $6.70^{\mathrm{a}}$ & $3.52^{\mathrm{a}}$ \\
$\mathbf{C C}$ & $7.31^{\mathrm{a}}$ & $7.13^{\mathrm{a}}$ & $6.78^{\mathrm{a}}$ & $6.62^{\mathrm{abc}}$ & $6.77^{\mathrm{a}}$ & $3.44^{\mathrm{a}}$ \\
$\mathbf{K}$ & $5.74^{\mathrm{c}}$ & $6.23^{\mathrm{c}}$ & $5.56^{\mathrm{b}}$ & $6.01^{\mathrm{c}}$ & $5.70^{\mathrm{c}}$ & $2.74^{\mathrm{b}}$ \\
$\mathbf{K C}$ & $6.42^{\mathrm{b}}$ & $6.31^{\mathrm{bc}}$ & $5.55^{\mathrm{b}}$ & $6.03^{\mathrm{bc}}$ & $5.92^{\mathrm{bc}}$ & $2.70^{\mathrm{b}}$ \\
\hline
\end{tabular}

Means \pm standard deviation with the same letters in the same column do not differ statistically $(\mathrm{p} \leq 0.05)$ by the Tukey test. $\mathrm{T}-$ salted cereal bar of dried tomato; TC - salted cereal bar of dried tomato with a layer of cheese; C - salted cereal bar of dehydrated carrot; CC - salted cereal bar of dehydrated carrot with a layer of cheese; $\mathrm{K}$ - salted cereal bar of fresh kale and KC salted cereal bar of fresh kale with a layer of cheese. Source: Authors (2020).

There was no significant difference ( $p>0.05$ ) between the samples that contained the cheese layer and those that did not contain for the same flavor to all evaluated attributes, except for the color in samples with the addition of kale (K and $\mathrm{KC}$ ).

Regarding the color and aroma attributes, the samples T, TC, C, and CC were more accepted with results between 6 ("liked slightly") and 8 ("liked a lot"). Thus, the obtained results were satisfactory for these formulations. The formulation K was the least accepted in these aspects and it was evident that the presence of the cheese layer increased the acceptance by the assessors significantly $(\mathrm{p} \leq 0.05)$ for the color parameter, but did not significantly influence the aroma $(\mathrm{p}>0.05)$. For flavor, texture and overall appearance attributes, dried tomato, and carrot cereal bar samples were also the most accepted, within the range between 6 ("liked slightly") and 7 ("liked moderately").

Only the kale samples $(\mathrm{K})$ differed from the other flavors $(\mathrm{p} \leq 0.05)$ for overall appearance and samples $\mathrm{K}$ and $\mathrm{KC}$ presented lower purchase intentions, obtaining rejection in this parameter, although in the other attributes they were shown to be intermediate.

The AI for the overall appearance ranged from $63.38(\mathrm{~K})$ to $76.76(\mathrm{TC})$ and only the kale samples showed an AI fewer than $70 \%$. According to Dutcosky (2011), for a product to be acceptable, the AI must be equal to or greater than $70 \%$. Therefore, the formulations T, TC, C, and CC showed satisfactory results.

Thus, salted cereal bars with dried tomatoes and carrots were more accepted than kale bars, with no statistical difference ( $p>0.05$ ) for all attributes. Probably because the kale, when heated, becomes darker and tends to present a bitter taste to the product that may have influenced the sensory acceptance.

The mean scores obtained in the sensory analysis were similar to those reported by Haddad et al. (2020) that presented results between 5 and 7 for the attributes texture, flavor, and general impression, and between 2 and 4 for purchase intention. Silva et al. (2009) also reported similar averages for the attributes of texture, flavor, and overall impression, between 5 and 8; however, the values were higher (between 3.7 and 4.4) to purchase intention for cereal bars with passion fruit residue.

Figure 1 shows the answers obtained in the questionnaire to characterize the evaluators' profile in sensory analysis. 
Figure 1: Reason for the consumption of cereal bars (a) and frequency of physical activity and consumption of cereal bars by the evaluators (b).

a

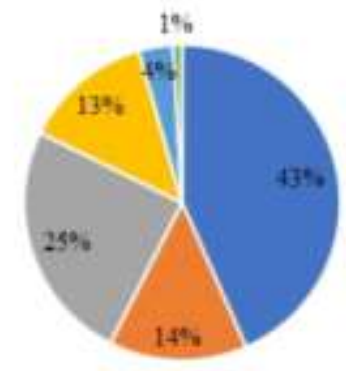

- Practicaliry

* Healithy

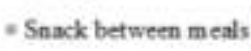

* Flavor

- Diet

- Other

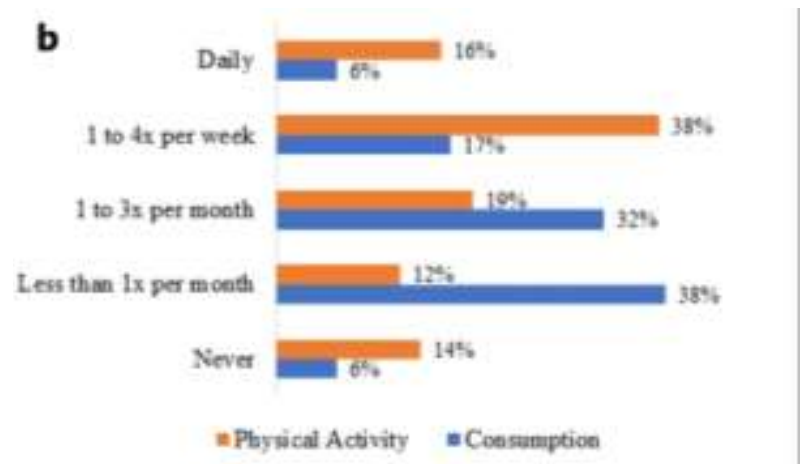

Source: Authors (2020).

The main reason for the consumption of cereal bars pointed by the assessors was the practicality (43\%), followed by the snack between meals (25\%), healthy characteristics (14\%), and flavor (13\%). Thus, the data prove that demand for cereal bars in the market is because they are considered healthy and at the same time convenient, practical, and tasty.

Haddad et al. (2020) also characterized the profile of the assessors in sensory analysis of salted cereal bars and found that the main reason for consumption was practicality, followed by taste and nutritional value, which is similar to the results obtained in this research. Therefore, the cereal bars have a great market potential as they meet the demands arising from changes in eating habits, which are due to urbanization, changes in family structure and lifestyle, the insertion of women in the labor market, increased access to information and education and increased purchasing power (Ital, 2010).

Regarding the frequency of physical activity, $38 \%$ of the assessors said they exercised one to four times a week, $19 \%$ one to three times a month, $16 \%$ daily, $14 \%$ never, and $12 \%$ less than once a month. Thus, it could be seen that more than $50 \%$ of the participants perform physical exercises regularly. As for the frequency of consumption, $38 \%$ consume cereal bars less than once a month, $32 \%$ one to three times a month, $17 \%$ one to four times a week, $6 \%$ daily, and $6 \%$ never. Therefore, it was noticed that at least $23 \%$ of the assessors consume this product at least once a week.

Only $6 \%$ of participants had already consumed salted cereal bars before sensory analysis, which confirms the fact that this product is not commonly found in the Brazilian market, which is an opportunity for innovation in a market niche.

Referring to the adjectives that best describe the samples proved, participants could check more than one option. The results obtained were: $70 \%$ of the evaluators characterized them as different; $65 \%$ innovative; $53 \%$ healthy; $45 \%$ tasty; $35 \%$ functional; $34 \%$ interesting; $10 \%$ strange; $6 \%$ sensational; $3 \%$ normal; $3 \%$ dull and $1 \%$ bad. Thus, most evaluators rated the products with positive adjectives, which demonstrates good acceptance of the developed savory cereal bars.

\section{Conclusion}

The results of this study showed that it is possible to develop salted cereal bars with the addition of vegetables rich in carotenoids and obtain good nutritional, physicochemical, and sensory characteristics. Formulations with dried tomato and with carrot can be marketed as a "source of protein" and the formulation with kale as "high protein content". The cereal bars with dried tomatoes and carrots were the most accepted for all the attributes evaluated, while kale bars, from a sensory point of view, would be the least unfeasible option. It was also concluded that the development of salted cereal bars is a niche to be explored by the Brazilian food industry with a great opportunity to innovate. For future research, it is interesting to evaluate the stability of cereal bars produced during storage, the possibility of reducing the fraction of binders or increasing temperature and/or cooking time to reduce moisture and develop other flavors. 


\section{References}

American Oil Chemists' Society - AOCS. (1993). Official methods and recommended practices (4th ed.). Champaign: AOCS.

Bampi, G. B., Backes, G. T., Cansian, R. L., de Matos, F. E., Ansolin, I. M. A., Poleto, B. C.; Corezzolla, L. R. Fávaro-Trindade, C. S. (2016). Spray Chilling Microencapsulation of Lactobacillus acidophilus and Bifidobacterium animalis subsp. lactis and Its Use in the Preparation of Savory Probiotic Cereal Bars. Food and Bioprocess Technology, 9(8), 1-7.

Bastos, D. H., Rogero, M. M., \& Arêas, J. A. G. (2009). Mecanismos de ação de compostos bioativos dos alimentos no contexto de processos inflamatórios relacionados à obesidade. Arquivos Brasileiros de Endocrinologia \& Metabologia, 53(5), 646-656.

Bezerra, C. C., \& Macedo, E. M. C. (2013). Consumo de suplementos a base de proteína e o conhecimento sobre alimentos proteicos por praticantes de musculação. Revista Brasileira de Nutrição Esportiva, 7(40), 224-232.

Brasil, Comissão Nacional de Normas e Padrões para Alimentos (CNNPA) (1978). Aprova Normas Técnicas Especiais, do Estado de São Paulo, revistas pela CNNPA, relativas a alimentos (e bebidas), para efeito em todo território brasileiro (Resolução CNNPA $n^{\circ} 12$, de 1978). Diário Oficial da República Federativa do Brasil.

Brasil, Ministério da Saúde. (2012). Dispõe sobre o Regulamento Técnico sobre Informação Nutricional Complementar (RDC $n^{\circ} 54$, de 12 de novembro de 2012). Diário Oficial da República Federativa do Brasil.

Costa, N. M. B., \& Rosa, C. O. B. (2010) Alimentos Funcionais - Componentes Bioativos e Efeitos Fisiológicos, Corantes Naturais: Usos e Aplicações como compostos bioativos. 243-264. Editora Rubio.

Dutcosky, S. D. (2011). Análise sensorial de alimentos (3a ed.). Champagnat.

Freitas, D. G. C., \& Moretti, R. H. (2006a). Barra de cereais de elevado teor protéico e vitamínico: estabilidade enzimática e das vitaminas C e E durante armazenamento. Archivos Latinoamericanos de Nutricion, 56(3), 269-274.

Freitas, D. G. C., \& Moretti, R. H. (2006b). Caracterização e avaliação sensorial de barra de cereais funcional de alto teor protéico e vitamínico. Ciência e tecnologia de alimentos, 26(2), 318-324.

Freitas-Machado, F. M. V., Barbalho, S. M., Oshiiwa, M., Goulart, R., \& Pessan Junior, O. (2012). Use of cereal bars with quinoa (Chenopodium quinoa W.) to reduce risk factors related to cardiovascular diseases. Food Science and Technology, 32(2), 239-244.

Gava, A. J., Silva, C. A. B., \& Frias, J. R. G. (2009). Tecnologia de alimentos: princípios e aplicações. Nobel.

Haddad, F. F., Ribeiro, A. P. L., Picinin, C. T. R., Píccolo, M. P., \& Barcelos, M. de F. P. (2020). Technological and nutritional aspects of salted food bars manufactured with different binding agents. Research, Society and Development, 9(11), e8269119958.

Instituto Adolfo Lutz - IAL (2008). Normas analíticas do Instituto Adolfo Lutz (4a ed.). Instituto Adolfo Lutz.

Ital - Instituto de Tecnologia de Alimentos (2010). Brasil Food Trends 2020. ITAL/FIESP. http://www.alimentosprocessados.com.br/arquivos/Consumotendencias-e-inovacoes/Brasil-Food-Trends-2020.pdf.

Marchese, N. R., \& Novello, Z. (2017). Desenvolvimento e caracterização de barra de cereal salgada. Revista Brasileira de Tecnologia Agroindustrial, 11(1), $2150-2164$

Medeiros, G. R., Kwiatkowski, A., Clemente, E., \& Costa, J. M. C. (2011). Avaliação de carotenóides em cenoura e análise sensorial de barras de cereais elaboradas com cenoura desidratada. Revista Brasileira de Tecnologia Agroindustrial, 5(1), 306-313.

Melo, P. F., Kalschne, D. L., Silva-Buzanello, R. A., Amaral, J. S., Torquato, A. S., Corso, M. P., Falcão, H. G., Colla, E., Ida, E. I. \& Canan, C. (2020). Cereal bars functionalised with tempeh: nutritional composition, isoflavone content and consumer acceptance. International Journal of Food Science \& Technology, 55, 397-405.

Mesquita, S. S., Teixeira, C. M. L. L., \& Servulo, E. F. C. (2017). Carotenoides: Propriedades, Aplicações e Mercado. Revista Virtual de Química, 9(2), 672688.

Nachtigall, A. M., Stringheta, P. C., Fidelis, P. C., \& Nachtigall, F. M. (2007). Determinação do teor de luteína em hortaliças. Boletim do Centro de Pesquisa de Processamento de Alimentos, 25(2), 181-192.

Nepa - Núcleo de Estudos e pesquisas em Alimentação / Unicamp - Universidade Estadual de Campinas. (2011). Tabela brasileira de composição de alimentos - TACO (4. ed.). Campinas: NEPA-UNICAMP.

Pereira, A. S., Shitsuka, D. M., Pereira, F. J., \& Shitsuka, R. (2018). Metodologia da pesquisa científica. UFSM. https://repositorio.ufsm.br/bitst ream/handle/1/15824/Lic_Computacao_Metodologia-Pesquisa-Cientifica.pdf?sequence=1.

Rodrigues Júnior, S., Patrocinio, I. M., Peña, W. E. L., Junqueira, M. S., \& Teixeira, L. J. Q. (2011). Desenvolvimento de barra de cereal salgada enriquecida com farinha de albedo de maracujá. Enciclopédia Biosfera, 7(12), 1-7.

Rodriguez-Amaya, D. B. (1999). A guide to carotenoid analysis in foods. Washington, D. C.: International Life Sciences Institute Press.

Rodriguez-Amaya, D. B. (2008). Fontes brasileiras de carotenóides: tabela brasileira de composição de carotenóides em alimentos (2a ed.). Brasília: MMA/SBF.

Sampaio, C. R. P., Ferreira, S. M. R., \& Canniatti-Brazaca, S. G. (2009). Perfil sensorial e aceitabilidade de barras de cereais fortificadas com ferro. Alimentos e Nutrição, 20(1), 95-106. 
Research, Society and Development, v. 10, n. 2, e44210212824. 2021

(CC BY 4.0) | ISSN 2525-3409 | DOI: http://dx.doi.org/10.33448/rsd-v10i2.12824

Schiozer, A. L., \& Barata, L. E. S. (2007). Estabilidade de Corantes e Pigmentos de Origem Vegetal. Revista Fitos, 3(2), 6-24.

Silva, I. Q., Oliveira, B. C. F., Lopes, A. S., \& Pena, R. S. (2009). Obtenção de barra de cereais adicionada do resíduo indu strial de maracujá. Alimentos e Nutrição, 20(2), 321-329.

Silva, L. A. A. da, Norões, A. R. L., Soares, T. da C., Cavalcante, R. M. S., \& Medeiros, S. R. A. (2019). Cereal Bar Fortified Development with the Addiction Vegetables: Carrot (Daucus carota L.) and Beet (Beta vulgaris L.). Research, Society and Development, 8(1), e2681598.

Tibco Software Inc. (2017). Statistica (data analysis software system), version $13.3 \mathrm{http}: / /$ statistica.io.

Tramujas, J. N., de Carli, C. G., Vieira do Prado, N., Lucchetta, L., Benedetti-Tonial, I. (2017). Assessment of nutritional and lipid quality of salted cereal bars prepared with different binding agents. Revista Chilena de Nutricion, 44, 350-359.

Valduga, E., Tatsch, P. O., Tiggemann, L., Treichel, H., Toniazzo, G., Zeni, J., Di Luccio, M. \& Júnior, A. F. (2009). Produção de carotenoides: microrganismos como fonte de pigmentos naturais. Química Nova, 32(9), 2429-2436.

Whitney, E., \& Rolfes, S. R. (2013). Nutrição, vol. 1: entendendo os nutrientes, As Vitaminas Lipossolúveis A, D, E e K, 193-221. Cengage Learning. 